\title{
Solanaceae na Reserva Rio das Pedras, Mangaratiba, Rio DE JANEIRO - BRASIL
}

\author{
Lúcia d’Ávila Freire de Carvalho ${ }^{1}$ \& Massimo G. Bovini ${ }^{1}$
}

\section{Resumo}

(Solanaceae na Reserva Rio das Pedras, Mangaratiba, Rio de Janeiro - Brasil) Foi realizado um estudo morfológico e taxonômico da família Solanaceae na Reserva Rio das Pedras, município de Mangaratiba situado no estado do Rio de Janeiro, um fragmento de floresta pluvial atlântica. Registrou-se 33 espécies pertencentes a 10 gêneros, sendo Solanum o mais expressivo. Solanum hirtellum e Solanum pensile são documentados pela primeira vez nesse estado. São apresentadas chave de identificação, descrições e ilustrações. Palavras-chave: Solanaceae, Rio de Janeiro, taxonomia, floresta pluvial atlântica.

\section{Abstract}

(Solanaceae of the Rio das Pedras Reserve, Mangaratiba, Rio de Janeiro - Brasil) It was developed a morphological and taxonomic study of the Solanaceae family at Rio das Pedras Reserve, which represents a fragment of the Atlantic Rain Forest, in the municipality of Mangaratiba, at Rio de Janeiro State. There were registered 33 species of 10 genera, being Solanum the most representative. Solanum hirtellum and Solanum pensile are documented for the first time for Rio de Janeiro State. A key for identification is presented, as well as, descriptions and illustrations.

Key-words: Solanaceae, Rio de Janeiro, taxonomy, Atlantic rain forest.

\section{INTRODUÇÃO}

Solanaceae é uma das maiores famílias entre as angiospermas, com cerca de 2.300 espécies subordinadas a 92 gêneros. Segundo Hunziker (2001), apresenta ampla distribuição geográfica e está concentrada principalmente na América do Sul, onde estima-se a presença de aproximadamente 50 gêneros endêmicos.

Para o Brasil não existe nenhuma avaliação recente para a diversidade de espécies de Solanaceae, à exceção da monografia de Sendtner (1846), publicada na Flora brasiliensis.

No início deste século foram reconhecidos 27 gêneros para o Brasil, com base nas pesquisas bibliográficas e nos herbários visitados. Carvalho et al. (2001) indicaram para a região sudeste, em levantamento preliminar, 17 gêneros e 313 espécies. No estado do Rio de Janeiro são registrados, até a presente data, 15 gêneros e cerca de 118 espécies coletadas nos mais diversos ambientes (Carvalho 1997a, b).
Tendo em vista a escassez de estudos em Solanaceae para o estado do Rio de Janeiro, este trabalho teve como objetivo reconhecer e analisar as espécies de Solanaceae na Reserva Rio das Pedras, contribuindo para ampliar o conhecimento morfológico e taxonômico da família.

\section{Material e Métodos \\ Área de estudo}

A Reserva Rio das Pedras (RRP), situada no lado atlântico da Serra do Mar, inserida no Maciço da Serra da Bocaina, e localiza-se no município de Mangaratiba, estado do Rio de Janeiro, entre as coordenadas $22^{\circ} 59^{\prime} \mathrm{S}$ e $44^{\circ} 05^{\circ} \mathrm{W}$, possuindo cerca de 1.360 ha, apresentando-se em diversos níveis de sucessão, cujas altitudes variam de 20 a 1.050 metros, representando um dos poucos remanescentes de floresta pluvial atlântica neste estado.

No que diz respeito à hidrografia, é típica de região com alguns declives, e apresentando

Artigo recebido em 03/2005. Aceito para publicação em 11/2005.

${ }^{1}$ Pesquisadores do Instituto de Pesquisas Jardim Botânico do Rio de Janeiro. Rua Pacheco Leão 915 - Gávea. CEP. 22460030. 1freire@jbrj.gov.br; mbovini@jbrj.gov.br 
o contorno externo da Reserva, a linha do divisor de águas da bacia do Rio Grande, que é bem definido e abrupto. A Reserva é formada pela bacia do Rio Grande (Fig. 1).

O clima é subquente (Nimer, apud Vidal 1995) com temperaturas médias anuais de $22^{\circ} \mathrm{C}$ e temperatura máxima absoluta de $38^{\circ} \mathrm{C}$. A grande variação de altitude, próxima ao litoral, é responsável pela precipitação máxima que corresponde aos meses de dezembro, janeiro e fevereiro.

\section{Campo e laboratório}

Foram realizadas expedições de campo durante cinco anos na RRP, em diversas trilhas existentes e algumas recuperadas, e coletadas, sempre que possível, amostras de indivíduos com flores e/ou frutos. A preparação do material botânico, proveniente das expedições, seguiu o método tradicional de herborização, para posterior inclusão nos herbários $\mathrm{RB}$ e
RUSU (siglas de acordo com Holmgren et al., 1990). O material foi identificado por meio de chaves analíticas, descrições e ilustrações constantes em bibliografia especializada, comparações com coleções botânicas e quando possível com o material-tipo. As ilustrações foram realizadas com o auxílio do microscópio estereoscópico, às vezes acoplados a câmara clara.

Os táxons apresentados nas descrições seguem a ordem alfabética para gêneros e espécies. Os nomes vulgares, quando indicados, foram fornecidos pelos acompanhantes do local. É importante ressaltar que, em cada táxon estudado, usou-se a nomenclatura e a distribuição geográfica da última revisão deste, quando existente. Quanto ao padrão de nervação adotou-se Leaf Architecture Working Group (1999) e para a classificação da vegetação, Veloso et al. (1991).

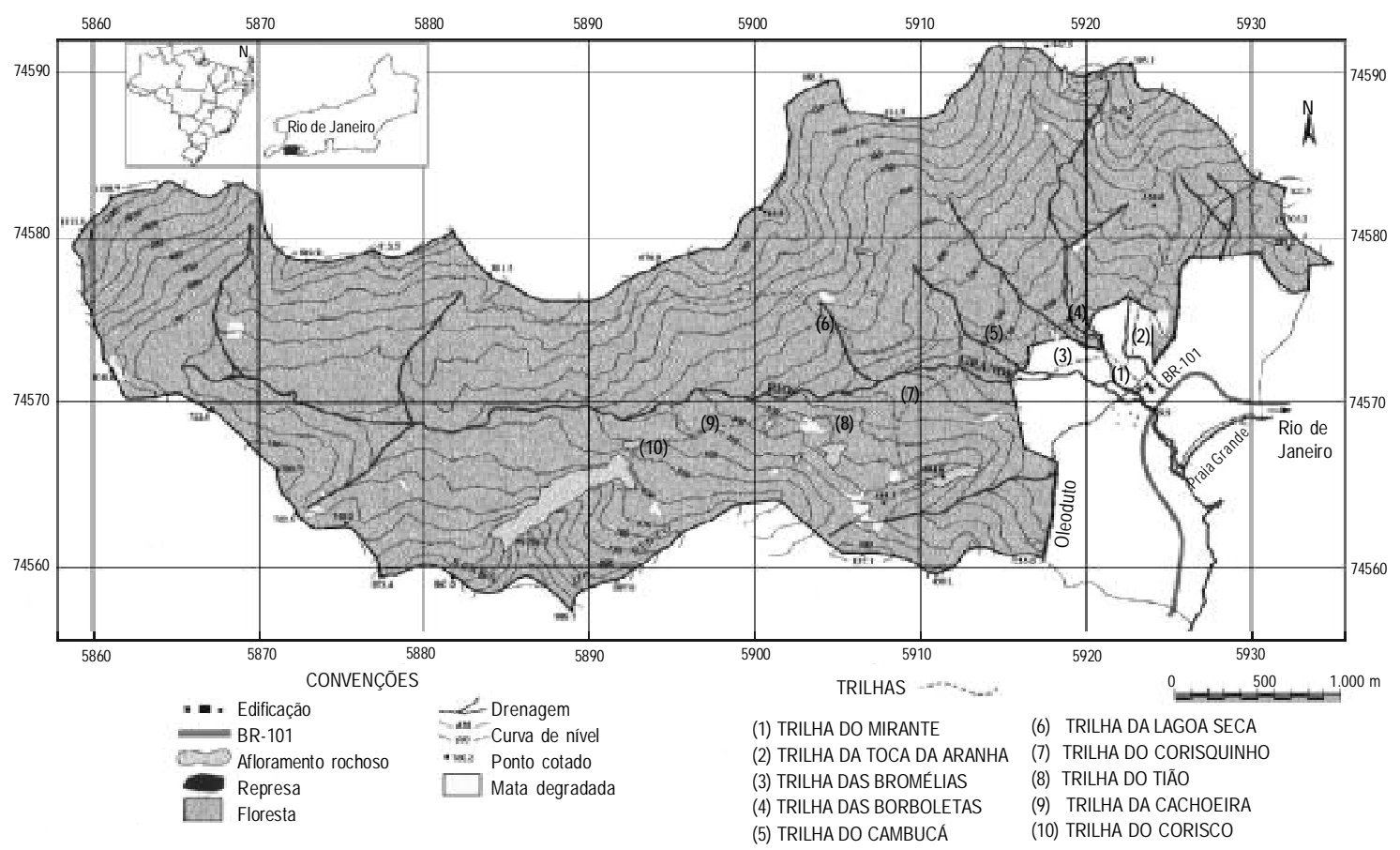

Figura 1 - Mapa da Reserva Rio das Pedras, Mangaratiba, Rio de Janeiro. Modificado de Agrofoto Aerofotogrametria S/A (1999). 


\section{Resultados e Discussão}

Solanaceae A. Juss.

Herbáceas, arbustivas, arbóreas, escandentes ou hemi-epífitas, glabras ou com indumento, diversos tipos de tricomas, espinhos e/ou acúleos. Ramos ascendentes ou patentes, dicotômicos iguais ou desiguais, cilíndricos ou aplanados, concaulescência presente. Folhas pecioladas ou subsésseis, alternadas, isoladas e/ou aos pares; lâminas inteiras, lobadas à pinatissectas ou as vezes dimorfas, nervação camptódroma, raro broquidódroma e craspedódroma. Flores isoladas e/ou em inflorescências axilares e/ou terminais, ou opostas as folhas, fasciculadas, racemosas, corimbosas ou paniculadas, raro bracteoladas. Flores hermafroditas, diclamídeas, heteroclamídeas, actinomorfas raro com simetria bilateral, prefloração valvar, valvar-plicada, imbricada, rotáceas, campanuladas, infundibuliformes, hipocrateriformes ou tubulosas; androceu pentâmero ou tetrâmero-didínamo, filetes retos, reflexos ou geniculados, anteras monotecas ou bitecas, com deiscência rimosa longitudinal de alvacentas a acastanhadas (Acnistus, Athenaea, Aureliana, Capsicum, Cestrum, Dyssochroma e Physalis), transversal (Brunfelsia), ou poricida amarelas ou lilases, apicais ou introrsas (Solanum); gineceu de ovário súpero, bilocular, placentação axilar, multiovulado, nectarífero ou nâo, estilete simples, estigma apical. Cápsula ou baga, por vezes envolvidos pelo cálice acrescente; sementes poucas a numerosas.

\section{Chave para o reconhecimento das espécies de Solanaceae na RRP}

1. Plantas armadas.

2. Plantas escandentes; lâmina foliar pinatissecta, pseudo-imparipenada, 5-7 segmentos 16. Solanum alternatopinnatum

2'. Plantas eretas; lâmina foliar lobada a partida.

3. Plantas até $1 \mathrm{~m}$ alt.; densamente aculeado-acicular; lâmina foliar irregular partida; tricomas simples 19. Solanum capsicoides

3'. Plantas mais de 1,5 m alt.; esparso aculeado-uncinado; lâmina foliar lobado-denteada; tricomas estrelados subsésseis ou pedicelados.

4. Lâmina foliar com base truncada a subcordada; nervação craspedódroma; cálice com lacínias aciculares; corola alva 33. Solanum tabacifolium

4'. Lâmina foliar com base atenuada; nervação camptódroma; cálice com lacínias ovadoapiciuladas; corola violácea 22. Solanum hexandrum

1'. Plantas inermes.

5. Plantas herbáceas eretas; corola amarela; cálice frutífero ampliado, inflado com as lacínias reunidas no ápice

5'. Plantas lenhosas, escandentes ou eretas; corola nunca amarela; cálice frutífero quando ampliado nunca inflado.

6. Plantas hemi-epífitas escandentes ou terrestres com ramos flexuosos.

7. Hemi-epífita; corola verde, lacínias "enroladas" .......... 14. Dyssochroma viridiflora

7'. Nunca hemi-epífita; corola alva, amarelo-esverdeada ou lilás, lacínias nunca "enroladas".

8. Ramos dicotômicos; lâmina foliar membranácea; inflorescência extra-axilar na dicotomia do ramos; corola campanulada; anteras com conectivo vinoso, expandido.

9. Lâmina foliar inteira a pinatissecta na mesma planta; conectivo giboso 27. Solanum parallum

9'. Lâmina foliar inteira; conectivo giboso espessado na região basal. 
10. Lâmina foliar ovado-oblonga a cordada; tricomas simples ao longo da nervura mediana; estigma expandido com corpúsculos globosos, inclusos

21. Solanum diploconos

10'. Lâmina foliar ovado-lanceolada; tricomas glandulares diminutos; estigma expandido sem corpúsculos 25. Solanum melissarum

8'. Ramos não dicotômicos; lâmina foliar membranácea a cartácea; inflorescência terminal; corola rotácea; anteras sem conectivo.

11. Folhas isoladas nos ângulos ramulares; nervação secundária com espaçamento irregular; botões oblongo-apiculados; corola sempre alva 26. Solanum odoriferum

11'. Folhas isoladas em ramos retos; nervação secundária com espaçamento uniforme; botões oblongos; corola de alva a lilás

28. Solanum pensile

6'. Plantas sempre terrestres sem ramos flexuosos.

12. Lâmina foliar prateada, acastanhada ou dourado-claro na face abaxial.

13. Lâmina foliar 20-60 cm compr.; inflorescência pêndula; tricomas paleáceos evidentes, acastanhados 20. Solanum castaneum

13'. Lâmina foliar menor que 15 cm compr.; inflorescência, ereta; tricomas peltados e peltadoestrelados.

14. Lâmina foliar alvacenta a prateada, broquidódroma, de nervação secundária com espaçamento uniforme; cálice frutífero persistente, bagas oblongo-apiculadas .....

18. Solanum argenteum

14'. Lâmina foliar alvacenta a dourado-claro, camptódroma a camptobro-quidódroma, de nervação secundária com espaçamento irregular; cálice frutífero envolvendo parcialmente a baga globosa .....32. Solanum swartzianum subsp. swartzianum var. swartzianum

12'. Lâmina foliar nunca prateada, acastanhada ou dourado claro.

15. Ramos com uma folha na dicotomia; corola geralmente com máculas verdes.

16. Ramos dicotômicos iguais, afilando em direção ao ápice; lâminas foliares membranáceas translúcidas.

17. Plantas tomentosas, alvacentas

9. Capsicum villosum var. villosum 17'. Plantas glabras.

18. Cálice truncado; corola rotáceo-estrelada

7. Capsicum campylopodium

18'. Cálice laciniado-linear; corola campanulado-laciniada

8. Capsicum recurvatum

16'. Ramos dicotômicos desiguais; lâminas foliares semi-cartácecas.

19. Lacínias do cálice longo-acuminadas .......................... 3. Aureliana darcyi

19'. Lacínias do cálice denteadas ......... 4. Aureliana fasciculata var. fasciculata

15'. Ramos sem dicotomia; corola sem máculas ou quando presente, vinosa.

20. Plantas geralmente de margem de rio; flores alvas, corola infundibuliforme.

21. Inflorescências caulinares, fasciculadas eretas; fruto globoso; cálice persistente;

ca. 60 sementes

1. Acnistus arborescens

21'. Flores isoladas, axilares, pêndulas; fruto fusiforme, cálice marcescente; ca.

12 sementes

5. Brugmansia suaveolens

20'. Plantas de borda ou de interior de floresta ou ainda de ambientes perturbados; flores alvas, azuladas ou esverdeadas; rotácea, campanulada, hipocrateriforme ou tubulosa. 
22. Corola azulada; hipocrateriforme; fruto capsular envolvido pelo cálice ampliado

6. Brunfelsia brasiliensis subsp. macrocalyx

22'. Corola alva, creme-esverdeada ou amarelada; rotácea, campanulada ou tubulosa; fruto bacáceo.

23. Folhas estipuláceas aos pares; corola creme-esverdeada ou amarelada; tubulosa a estreito infundibuliforme; baga oblonga ou ovóide.

24. Lâmina foliar cartácea, até $22,5 \times 10 \mathrm{~cm}$; folhas estipuláceas ovadas, base oblonga a cordada 10. Cestrum corcovadense

24 '. Lâmina foliar membranácea, até $15 \times 5 \mathrm{~cm}$; folhas estipuláceas lanceoladas a ovadorecurvadas.

25. Folhas estipuláceas ovado-recurvadas; inflorescências racemos de pseudocorimbos, axilares 11. Cestrum intermedium

25'. Folhas estipuláceas lanceoladas; inflorescências paucifloras, fasciculadas ou racemosa.

26. Lâmina foliar com nervação secundária de espaçamento irregular; inflorescência fasciculada

13. Cestrum sendtnerianum

26'. Lâmina foliar com nervação secundária de espaçamento uniforme; inflorescência racemosa

12. Cestrum laevigatum

23'. Folhas estipuláceas ausentes; corola alva; rotácea ou campanulada; baga globosa a piriforme.

27. Planta viscosa; corola alva com máculas vinosas; cálice ampliado com nervação proeminente envolvendo o fruto 2. Atheneae picta

27'. Planta nunca viscosa; corola alva sem máculas; cálice frutífero nunca ampliado.

28. Folhas sempre aos pares, glabras ou apenas com domáceas pilíferas.

29. Arvoreta ou árvore; folhas aos pares, desiguais em tamanho, domáceas pilíferas; flores 15-20 em racemo; baga globosa

29. Solanum pseudoquina

29'. Subarbusto a arbusto; folhas aos pares, desiguais em tamanho e forma, glabras; flores 4-5 em cimeira; baga piriforme 31. Solanum stipulatum

$28^{\prime}$. Folhas isoladas, raramente aos pares, pilosas.

30. Lâmina foliar com tricomas simples; inflorescência extra-axilar, pseudo-umbela 17. Solanum americanum var. nodiflorum

30'. Lâmina foliar com tricomas estrelados; inflorescência em cimeira.

31. Lâmina foliar com a largura maior que a metade do comprimento; flores

7 em cimeira congesta

24. Solanum martii

31'. Lâmina foliar com a largura menor que a metade do comprimento; flores mais de 15 em cimeira dicotômica laxa.

32. Plantas com indumento hialino; lâmina foliar com ápice fortemente cuspidado; cálice frutífero não ampliado; fruto ca. 6 sementes

23. Solanum hirtellum

32'. Plantas com indumento ferrugíneo; lâmina foliar com ápice levemente acuminado; cálice frutífero ampliado; fruto ca. 25 sementes 30 . Solanum rufescens 
Acnistus Schott.

1. Acnistus arborescens (L.) Schltdt., Linnaea 7:67. 1832.

Figs. 2 a-c

Atropa arborescens L., Amoen. Acad. 4:307. 1759.

Árvore 4-6 m alt. Ramos esfoliantes, nodosos. Folhas inteiras, isoladas; lâminas até $23 \times 15 \mathrm{~cm}$, membranáceas, ovadas a lanceoladas, ápice agudo, base atenuada, camptódromas, nervuras secundárias com espaçamento irregular, pubescentes, tricomas simples, crespos na face abaxial; pecíolo ca. 2,5 cm compr., pubescente. Flores 10-20, fasciculadas, caulinares, pedicelo ca. $2 \mathrm{~cm}$ compr.; cálice urceolado, lacínias lanceoladas, desiguais; corola até $1 \mathrm{~cm}$ compr., alvoesverdeada, perfumada, prefloração valvar, campanulado-infundibuliforme, lacínias lanceoladas, revolutas; anteras oblongas, alvas, exsertos, filetes parcialmente concrescidos ao tubo corolíneo; ovário com disco nectarífero, heterostilia, estigma discóide. Baga ca. $5 \mathrm{~mm}$ diâm., globosa, cálice ampliado, ca. 60 sementes, 6-9 esclerócitos.

Material examinado: trilha do Cambucá, 15.IX.1996, fl.fr., J. A. Lira Neto et al. 369 (RUSU).

Distribuição geográfica: neotropical, desde o México, América Central, Antilhas até América do Sul. No Brasil é encontrada nas Regiões Nordeste, Sudeste e Sul (Hunziker 1982).

\section{Athenaea Sendtn.}

2. Athenaea picta (Mart.) Sendtn., in Martius, Fl. bras. 10: 134. 1846. Fig. $2 \mathrm{~d}-\mathrm{f}$ Witheringia picta Mart., Nov. Gen. sp. pl. 3: 74, t. 227. 1829.

Arvoreta ca. 2,5 m alt., viscosa. Ramos secundários ascendentes, alternados e terciários axilares, entre-nós esparsos até $4 \mathrm{~cm}$ distância, pubescentes, tricomas simples longos e glandulares-pedicelados. Folhas inteiras, aos pares, desiguais em tamanho ou isoladas; lâminas as maiores até $11 \times 6,5 \mathrm{~cm}$, membranáceas, oblongas a ovadas, ápice acuminado, base assimétrica, um tanto atenuada, camptódroma, nervuras secundárias com espaçamento irregular, oblongas a ovadas; pecíolo até $5 \mathrm{~cm}$ compr.; e as menores até $6 \times 3,5 \mathrm{~cm}$, pubescentes em ambas as faces, tricomas simples, longos; pecíolo até $3 \mathrm{~cm}$ compr. Flores 2-3, fascículos axilares, raro isoladas, pedicelo até $7 \mathrm{~mm}$ compr.; cálice com prefloração valvar, lacínias desiguais em tamanho, pubescentes, tricomas simples e glandularespedicelados; corola ca. 2 cm diâm., prefloração valvar, alva com máculas vinosas, rotáceoestrelada, lacínias lanceoladas até $9 \mathrm{~cm}$ compr., face interna com tricomas glandulares curtopedicelados; anteras oblongas, pardacentas, filetes concrescidos parcialmente com apêndices basais e laterais. Baga até $1 \mathrm{~cm}$ diâm., globosa, glabra, envolvida pelo cálice com nervação proeminente, ca. 21 sementes. Material examinado: trilha do Corisquinho, 200-400 m s.m., 26.IV.1997, fl., M. G. Bovini et al. 1162 (RUSU); trilha para a Toca da Aranha, 150-400 m s.m., 11.I.1999, fl.fr., $M$. G. Bovini et al. 1615 (RB, RUSU).

Distribuição geográfica: exclusiva do Brasil, ocorre nos estados da Bahia, Goiás, Região Sudeste, Paraná e Santa Catarina (Barbosa \& Hunziker 1989).

Espécie caracterizada pela presença do indumento constituído por tricomas glandulares, tornando-a viscosa ao contato. Na RRP os indivíduos cresceram sempre isolados em ambiente ciófilo.

\section{Aureliana Sendtn.}

3. Aureliana darcyi Carvalho \& Bovini, Novon 5(3): 257. 1995. Fig. $2 \mathrm{~g}$

Arvoreta 3-6 m alt., concaulescência evidente. Ramos dicotômicos desiguais, glabros a pubescentes, tricomas simples. Folhas aos pares, raro isoladas; lâminas até $9,5 \times 2,5 \mathrm{~cm}$, membranáceas a semi-cartáceas, lanceoladas, ápice agudo, base atenuada, às vezes assimétrica, decurrente, camptódromas, nervuras secundárias com espaçamento irregular, face abaxial pubescente, tricomas simples minúsculos; pecíolo até $1 \mathrm{~cm}$ compr. Flores 3-10, fasciculadas, axilares; pedicelo 

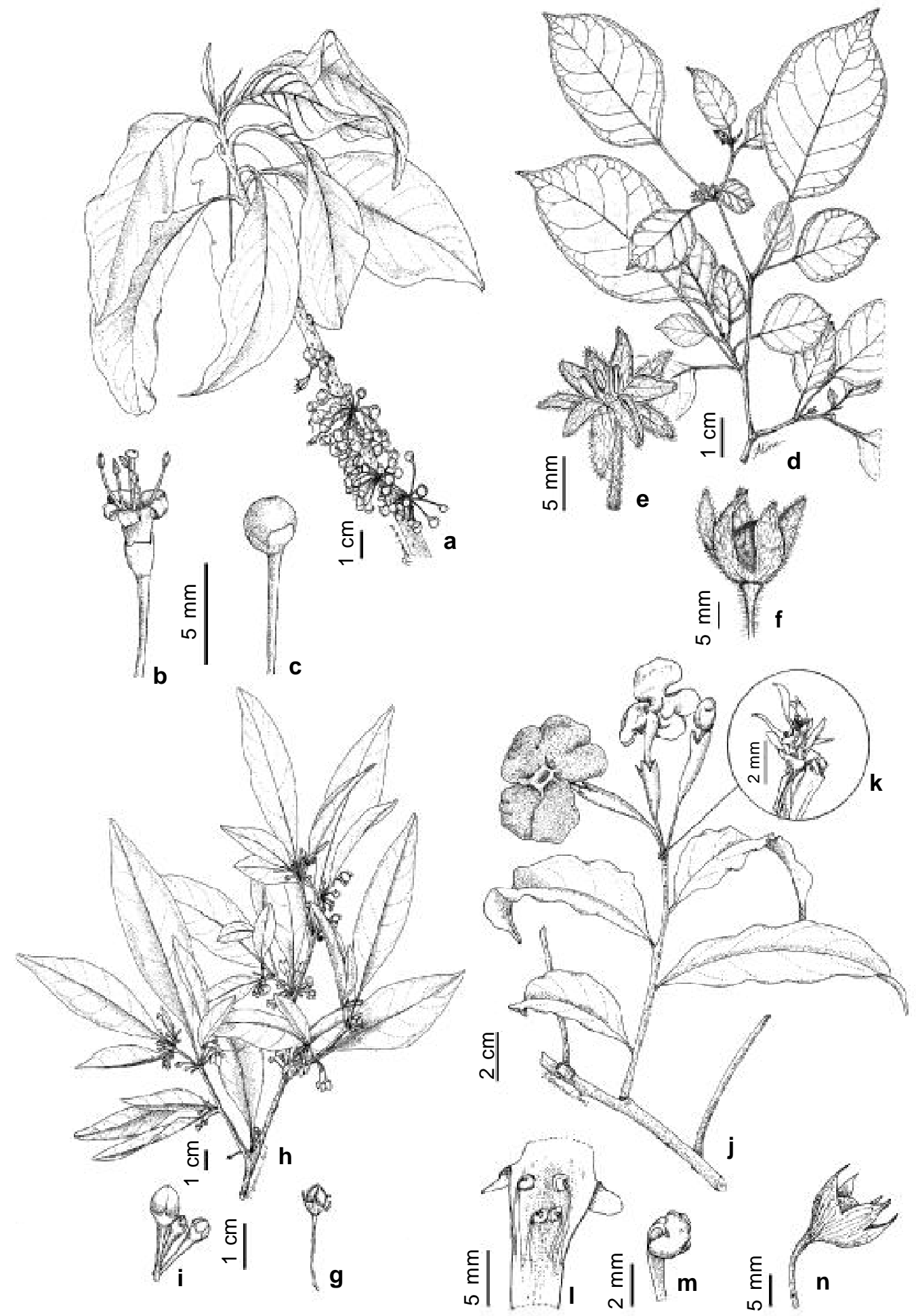

Figura 2 - Acnistus arborescens. a. ramo com flores e frutos; b. flor; c. fruto com cálice (Lira Neto 369). Athenaea picta. d. ramo com flores; e. flor; f. fruto envolvido pelo cálice (Bovini 1615.). Aureliana darcyi. g. lacínias longo-acuminadas do cálice (Bovini 1152). Aureliana fasciculata var.fasciculata. h. ramo com flores; i. lacínias denteadas do cálice (Lopes 131). Brunfelsia brasiliensis subsp. macrocalyx. j. ramo com flores; k. bractéolas; 1. tubo da corola evidenciando os estames didínamos; m. estame (Bovini 1906); n. cálice frutífero (Lira Neto 516). 
até $1 \mathrm{~cm}$ compr.; botões globosos; cálice campanulado, lacínias longo-acuminadas; prefloração valvar; corola ca. $1 \mathrm{~cm}$ diâm., alva com máculas verdes, rotáceo-estrelada, lacínias de margem ciliada, ápice cuculado; anteras oblongas, pardacentas, basifixas com apêndices laterais, estigma acima dos estames. Baga ca. 7 mm diâm., globosa, ca. 45 sementes.

Material examinado: trilha do Cambucá, 200300 m s.m., 23.III.1997, fl., M. G. Bovini et al. 1152 (RB, RUSU); trilha para o pico do Corisco, ca. 800 m s.m., 25.V.2000, fl., M. G. Bovini et al. 1804 (RUSU); idem, 23.V.2000, fl., M. G. Bovini et al. 1813 (RUSU).

Distribuição geográfica: endêmica do estado do Rio de Janeiro (Carvalho \& Bovini 1995).

É uma nova localidade de ocorrência para o estado. Própria de floresta pluvial atlântica, esta espécie é preferencialmente semiheliófila no sub-bosque.

4. Aureliana fasciculata (Vell.) Sendtn. var. fasciculata, in Mart., Fl. bras. 10: 140. 1846. Fig. 2 h, i

Solanum fasciculatum Vell., Fl. Flum. Icon. 2. tab. 106. (1827)1831; text. in Arch. Mus. Nac. Rio de Janeiro 5:81. 1881.

Arvoreta 3-6 m alt., concaulescência evidente. Ramos dicotômicos desiguais, glabros a pubescentes, tricomas simples. Folhas aos pares, raro isoladas; lâminas até $10 \times 3 \mathrm{~cm}$, membranáceas a semi-cartáceas, lanceoladas, ápice agudo, base atenuada, por vezes assimétrica, decurrente, camptódromas, nervuras secundárias com espaçamento irregular, face abaxial pubescente, tricomas simples, minúsculos; pecíolo até $1 \mathrm{~cm}$ compr. Flores 3-10, fasciculadas, axilares; pedicelo até $1 \mathrm{~cm}$ compr.; botões globosos; cálice campanulado, lacínias denteadas; prefloração valvar, corola ca. $1 \mathrm{~cm}$ diâm., alva com máculas verdes, rotáceo-estrelada, lacínias de margem ciliada, ápice cuculado; anteras oblongas, pardacentas, basifixas com apêndices laterais, estigma abaixo dos estames. Baga ca. 6 mm diâm., globosa, ca. 45 sementes, 1 esclerócito.

Material examinado: trilha do Cambucá, 200300 m s.m., 12/VI/1998, fl. fr., R. C. Lopes et al. 131 (RUSU); trilha para o Corisquinho, 24.III.1999, fl.fr., D. Bartholo et al. 09 (RUSU).

Distribuição geográfica: no Brasil ocorre nas Regiões Sudeste e Sul (Hunziker et al. 1991).

\section{Brugmansia Persoon}

5. Brugmansia suaveolens (Humb. \& Bonpl. ex Willd.) Bercht. \& Presl., Rostl. 1. Solaneae. 45. 1823.

Datura suaveolens Humb. \& Bonpl. ex Willd., Enum. Plant. Hort. Berol. 227. 1809.

Arbusto, 2-5 m alt. Ramos glabrescentes. Folhas inteiras, isoladas; lâminas até $25 \times 11 \mathrm{~cm}$, membranáceas, ovadas, ovadoelípticas, ápice agudo a acuminado, base obtusa, assimétrica, camptódroma, nervuras secun-dárias com espaçamento diminuindo para a base, tricomas simples na face abaxial; pecíolo ca. $4 \mathrm{~mm}$ compr. Flores isoladas, axilares, pêndulas; pedicelo ca. 3,5 cm compr., cálice verde, zigomorfo, espatáceo, 2-5-laciniado, desiguais em compr.; corola ca. $15 \mathrm{~cm}$ diâm., alva, infundibuliforme, 5 lacínias, estreito-lineares; anteras lineares, desiguais. Baga ca. $4 \mathrm{~cm}$ compr. (imatura), ovóide a oblonga, fusiforme, cálice frutífero marcescente, ca. 100 sementes.

Material examinado: trilha do Cambucá, margem de rio, 14.IX.1996, fl. fr., M. G. Bovini et al. 1044 (RB, RUSU).

Distribuição geográfica: provavelmente originária da região andina (Hunziker 2001). Amplamente cultivada pela beleza de suas flores e subespontânea nas mais diversas regiões brasileiras. 
Brunfelsia L.

6. Brunfelsia brasiliensis subsp. macrocalyx (Dusén) Plowman, Fieldiana, Bot., n.ser. 39:66.1998.

Fig. 2 j-n

Brunfelsia hopeana var. macrocalyx Dusén, Arch. Mus. Nac. Rio de Janeiro 13: 94. 1905.

Arbustos à arvoretas 2-5 m alt. Ramos esfoliantes. Folhas esparsas próximas ao ápice dos ramos; lâminas até $15 \times 4,5 \mathrm{~cm}$, membranáceas a cartáceas, lanceoladas, ápice levemente atenuado, base aguda, camptobroquidódromas a broquidódromas, nervuras secundárias com espaçamento aumentando em direção a base, glabras ou raros tricomas glandulares diminutos em ambas as faces; pecíolo ca. 1,2 cm compr. Flores 6-8, fascículos a racemos reduzidos na porção terminal dos ramos, subsésseis; pedicelo ca. 2 $\mathrm{cm}$ compr., articulado, cicatrizes anelares, tricomas glandulares; bractéolas 1-3 por flor, linear- lanceoladas, 3-7 mm compr.; cálice tubuloso, lacínias ca. 5 mm compr.; prefloração imbricada, corola ca. $4 \mathrm{~cm}$ compr., azulada, hipocrateriforme, breve inflado próximo à fauce; lacínias obovadas, ca. 3,2 cm compr., estames didínamos; filetes reflexos, planos, concrescidos parcialmente ao tubo corolíneo, anteras monotecas, oblongo-reniformes; estigma bífido. Cápsula ca. $2 \mathrm{~cm}$ compr., envolvida pelo cálice ampliado, campanuladourceolado, lenticelado, nervuras proeminentesespessadas, ca. 12 sementes.

Material examinado: trilha para a Lagoa Seca, 70-800 m s.m., 4.VIII.1999, fl., M. G. Bovini et al. 1665 (RB, RUSU); idem, 7.X.2000, fl., M. G. Bovini et al. 1906 (RUSU); trilha para o Corisquinho, 22.XII.1996, fr., J. A. Lira Neto et al 518 (RB, RUSU).

Distribuição geográfica: ocorre nos estados de Goiás, Minas Gerais, Espírito Santo, Rio de Janeiro, São Paulo, Paraná e Santa Catarina (Plowmann 1998).

Encontrada em ambiente semi-heliófilo da floresta pluvial atlântica. Na RRP apresentou-se isolada na maioria das vezes e não foi registrada em altitudes acima de 400 m s.m.

Capsicum L.

7. Capsicum campylopodium Sendtn., in Mart., Eichler \& Urban, Fl. bras. 10: 144. 1846. Fig. 3 a

Subarbusto 1,5 m alt., glabro. Ramos filiformes, patentes, dicotômicos iguais, afilando em direção ao ápice, entre-nós esparsos, uma folha na dicotomia. Folhas inteiras, isoladas; lâminas 2-laterais menores e 1 central maior, ca. $10 \times 3,5 \mathrm{~cm}$, membranáceas, translúcidas, lanceoladas, 3 folhas desiguais em tamanho em cada nó, ápice acuminado, base aguda, camptódromas a campto-broquidódromas, nervação secundária com espaçamento uniforme; pecíolo ca. $5 \mathrm{~cm}$ compr. Flores 2-3 fasciculadas, axilares ou isoladas na dicotomia dos ramos, pedicelo até $2 \mathrm{~cm}$ compr., um tanto ampliado e reflexo no ápice, articulado; cálice campanulado, truncado; corola ca. $8 \mathrm{~mm}$ compr., alva com máculas esverdeadas, prefloração valvar-plicada, rotáceo-estrelada, lacínias lanceoladas; anteras, oblongas, deiscência longitudinal lateral; filetes parcialmente concrescidos, com apêndices basais e laterais; estigma quase na mesma altura dos estames, clavado. Baga ca. $5 \mathrm{~mm}$ diâm., globosa, cálice persistente, 1 semente. Material examinado: trilha para a Lagoa Seca, 100-550 m s.m., 12.VII.1997, fr., M. G. Bovini et al. 1210 (RUSU); idem, 12.VII.1997, fr., M. G. Bovini et al. 1211 (RB, RUSU); trilha para a Toca da Aranha, 23.XI.1998, fl., M. G. Bovini et al. 1566 (RUSU); idem, 23.XI.2001, fl., M. G. Bovini et al. 2100 (RB, RUSU); idem, 21.X.1997, fl., J. M. A. Braga et al. 4361 (RUSU); trilha para o Cambucá, 20.X.1996, fl., J. A. Lira Neto et al. 444 (RUSU).

Distribuição geográfica: ocorre em nos estados da Região Sudeste e Santa Catarina (Carvalho 1997a). 
8. Capsicum recurvatum Witasek, Denkchr. Akad. Wiss. Wien Math. -Naturwiss. Kl. 79(2): 321. 1910.

Fig. 3 b, c

Subarbusto até $2 \mathrm{~m}$ alt., glabro. Ramos dicotômicos desiguais, afilando em direção ao ápice, entrenós esparsos com uma folha na dicotomia. Folhas inteiras, isoladas; lâminas 2 laterais menores e 1 central maior, ca. $20 \times$ $5,5 \mathrm{~cm}$ membranáceas, translúcidas, lanceoladas a ovado-lanceoladas, 3 folhas desiguais em forma e tamanho em cada nó, ápice atenuado, base aguda, camptódroma, nervação secundária com espaçamento diminuindo para a base; pecíolo até $1,3 \mathrm{~cm}$ compr. Flores 3, fasciculadas, axilares ou isoladas na dicotomia dos ramos; pedicelo ca. $2 \mathrm{~cm}$ compr., um tanto ampliado e reflexo no ápice, articulado; cálice campanulado, lacínias lineares; corola ca. $9 \mathrm{~mm}$ compr., alva com máculas acastanhado-verdes, campanuladolaciniada, lacínias lanceoladas; anteras oblongas, deiscência longitudinal lateral, filetes parcialmente concrescidos, com apêndices basais e laterais; estigma mesma altura dos estames, truncado. Baga ca. $7 \mathrm{~mm}$ diâm., globosa, cálice persistente, lacínias reflexas, 917 sementes nigrescentes.

Material examinado: trilha para o Corisquinho, 200-300 m s.m., 1.XII.1996, fl. fr., M. G. Bovini et al. 1119 (RB, RUSU); trilha para a Lagoa Seca, 200-300 m s.m., 27.V.1997, fr., M. G. Bovini et al. 1178 (RUSU); trilha para a casa do Tião, $250 \mathrm{~m}$ s.m., 7.I.2000, fr., M. G. Bovini et al. 1753 (RB, RUSU); trilha para o Corisquinho, 150 m s.m., 26.IV.1997, fl., J. M. A.Braga et al. 3973 (RB, RUSU).

Distribuição geográfica: ocorre nos estados do Rio de Janeiro e São Paulo (Carvalho, 1997a).

Espécie típica de floresta pluvial atlântica. Na RRP é muito freqüente em locais úmidos e protegidos no estrato herbáceo da floresta.
9. Capsicum villosum Sendtn. var. villosum in Mart., Fl. bras. 10: 144. 1846.

Subarbusto ca. 1,8 m alt., alvacento, tomentoso. Ramos dicotômicos desiguais, entre-nós esparsos, tomentoso, tricomas simples, longos. Folhas inteiras, isoladas ou em grupos de três desiguais; lâminas a maior até $14 \times 3,6 \mathrm{~cm}$, membranáceas, lanceoladas, ápice agudo-falcado, base atenuada, margem ciliada, camptódromas, nervação secundária com espaçamento irregular; pecíolo até $6 \mathrm{~mm}$ compr. Flores 2-5, fasciculadas axilares; pedicelo ca. 2 cm compr., reflexo no ápice; cálice campanulado, lacínias lineares, pubescentes; corola ca. $7 \mathrm{~mm}$ compr., alva com máculas verdes, lacínias denteadas, face interna papilosa; anteras oblongas, deiscência longitudinal lateral, filetes parcialmente concrescidos, com apêndices laterais e basais; estigma mesma altura dos estames, apical. Fruto não observado.

Material examinado: trilha do Cambucá, 70310 m s.m., 23.XI.1999, fl., M. G. Bovini et al. 1721 (RB, RUSU).

Distribuição geográfica: ocorre nos estados de Minas Gerais, Rio de Janeiro, São Paulo, Paraná e Santa Catarina (Carvalho 1997a).

\section{Cestrum L.}

10. Cestrum corcovadense Miers., London J. bot. 5. 160. 1846.

Fig. $3 \mathrm{~d}$

Arvoreta 3-4 m alt. Ramos cilíndricos, glabros. Folhas inteiras, isoladas; lâminas até ca. 22,5 × $10 \mathrm{~cm}$, cartáceas, ovada-elípticas, ápice agudo a acuminado, base decurrente, camptódromas, nervação secundária com espaçamento irregular; pecíolo até $3,5 \mathrm{~cm}$ compr., folhas estipuláceas aos pares, ovadas, base oblonga a cordada, sésseis, ca. 1,2 cm compr. Flores 5-10, em 2-3 racemos axilares, ca. $3 \mathrm{~cm}$ compr., pedúnculo $5 \mathrm{~mm}$ compr., pedicelo ca. $2 \mathrm{~mm}$ compr., bractéolas linearlanceoladas, até $3 \mathrm{~mm}$ compr.; cálice campanulado, laciniado, ciliado; corola ca. 1,5 $\mathrm{cm}$ compr., estreito-infundibuliforme, creme- 


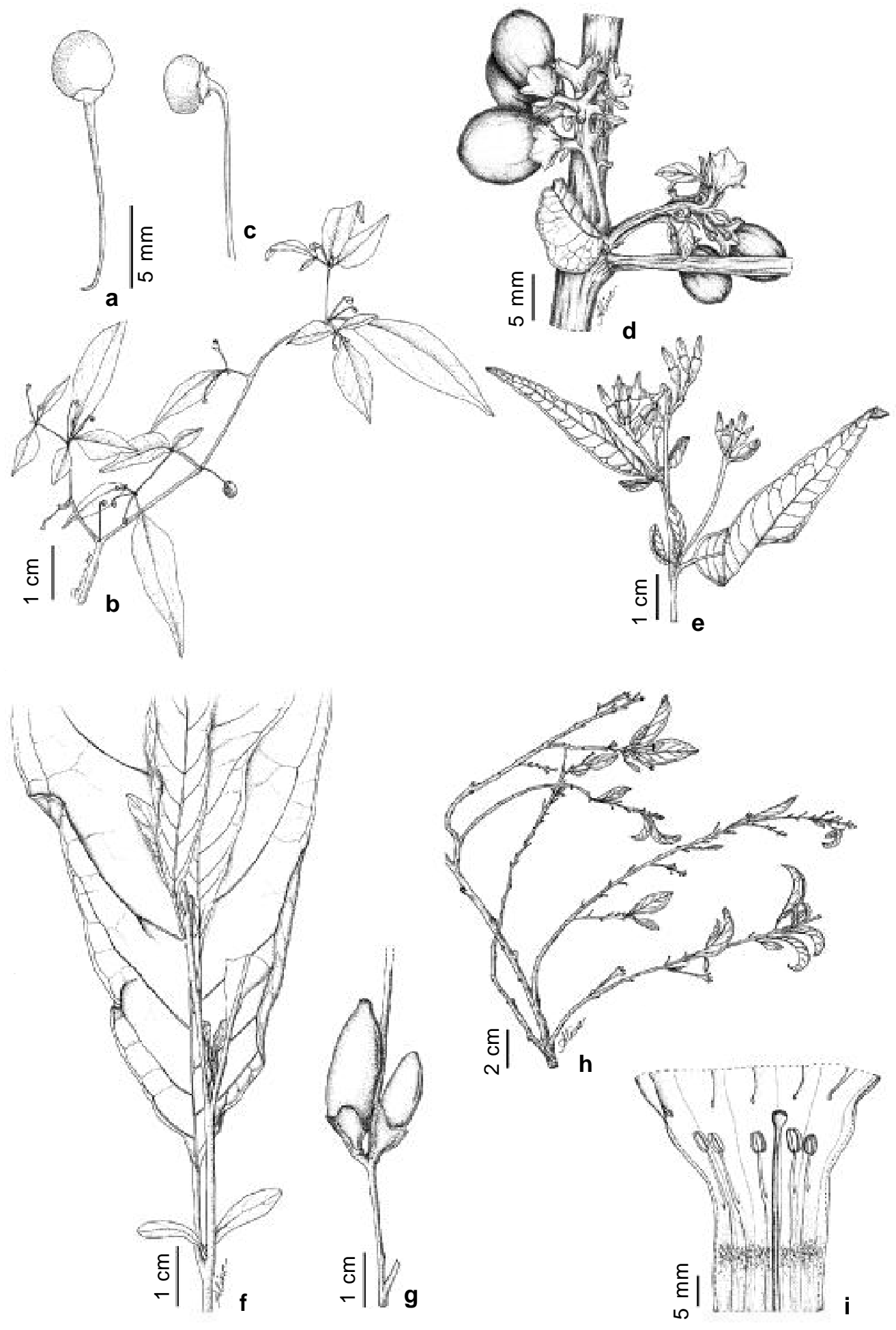

Figura 3 - Capsicum campylopodium. a. cálice frutífero truncado (Bovini 1211). Capsicum recurvatum. b. ramo com flores e frutos; c. cálice frutífero com lacínias lineares (Braga 3973). Cestrum corcovadense. d. ramo frutífero com folhas estípuláceas (Bovini 1214). Cestrum intermedium. e. ramo com flores, folhas estipuláceas (Lira Neto 505). Cestrum laevigatum. f. ramo vegetativo com folhas estipuláceas; g. frutos (Lira Neto 318). Cestrum sendtnerianum. h. ramo com flores; i. corola evidenciando estames adnatos e estilete/estigma (Braga 3987). 
esverdeada, lacínias lanceoladas,; anteras orbiculares, filete glabro, ca. $1 \mathrm{~cm}$ compr., adnato ao tubo e ca. $5 \mathrm{~mm}$ compr. livre, viloso na base; estigma incluso, mesma altura dos estames, capitado. Baga ca. 6 mm diâm., oblonga, cálice persistente, ampliado, 5-7 sementes.

Material examinado: trilha do cambucá, 20.X.1996, fl., J. A. Lira Neto et al. 436 (RUSU); trilha para a Lagoa Seca, 100-550 m s.m., 12.VII.1997, fr., M. G. Bovini et al. 1214 (RB, RUSU); trilha para a Lagoa Seca, 7.X.2000, fr., M. G. Bovini et al. 1907 (RUSU).

Distribuição geográfica: ocorre no estado da Bahia e Região Sudeste (Carvalho 1997a).

11. Cestrum intermedium Sendtn., in Mart., Fl. bras. 10: 221. 1846.

Fig. $3 \mathrm{e}$

Árvore ca. $10 \mathrm{~m}$ alt. Ramos cilíndricos, glabros. Folhas inteiras, isoladas; lâminas até $14 \times 4 \mathrm{~cm}$, membranáceas, lanceoladas, ápice atenuado, base aguda, camptódromas, nervação secundária com espaçamento uniforme; pecíolo até $1 \mathrm{~cm}$ compr.; folhas estipuláceas aos pares, ovado-recurvadas, ca. $1 \mathrm{~cm}$ compr., curto-pecioladas. Flores ca. 10, em racemos de pseudo-corimbos axilares, até $2 \mathrm{~cm}$ compr., subsésseis, botões turbinados, bractéolas foliares lanceoladas, até $2 \mathrm{~mm}$ compr.; cálice tubuloso, laciniado, densofimbriado; corola ca. $1,5 \mathrm{~cm}$ compr., estreitoinfundibuliforme, creme-esverdeada, lacínias lanceolada, papilosas,; anteras orbiculares, filete ca. $1 \mathrm{~cm}$ adnato ao tubo e ca. $5 \mathrm{~mm}$ livre, glabro; estigma acima dos estames, capitado. Fruto não observado.

Material examinado: trilha para o Corisquinho, 31.XI.1996, fl., J. A. Lira Neto et al. 505 (RB, RUSU)

Distribuição geográfica: ocorre nas Regiões Sudeste e Sul do Brasil (Carvalho 1997a).
12. Cestrum laevigatum Schltdl., Linnaea 7: 58. 1832.

Fig. 3 f, $g$

Árvore ca. $3 \mathrm{~m}$ alt.. Ramos cilíndricos, glabros. Folhas inteiras, isoladas; lâminas até $15 \times 5 \mathrm{~cm}$, membranáceas, lanceoladas a obovadas, ápice obtuso a acuminado, base aguda, decurrente, camptódromas, nervação secundária com espaçamento uniforme; pecíolo até $1,5 \mathrm{~cm}$ compr.; folhas ca. $2 \mathrm{~cm}$ compr., estipuláceas aos pares, lanceoladas, reflexas, Flores em racemos terminais até 34 cm compr. ou axilares, subsésseis, bractéolas ca. 2 mm compr.. Baga 1-2 cm compr., oblonga ou ovóide, cálice persistente, 5-8 sementes.

Material examinado: trilha para o Cambucá e margem do rio Grande, 18.VIII.1996, fr., J. A. Lira Neto et al. 318 (RUSU); trilha do Cambucá, 200-300 msm, 15.IX.1996, fr., $M$. G. Bovini et al. 1052 (RB, RUSU).

Distribuição geográfica: ocorre em todo o Brasil, exceto na Região Sul (Nee 2001).

13. Cestrum sendtnerianum Mart. ex Sendtn., in Mart., Fl. bras. 10: 215. 1846.

Fig. 3 h, i

Arbusto ca. $3 \mathrm{~m}$ alt. Ramos cilíndricos, glabros. Folhas inteiras, isoladas, decíduas; lâminas até $5 \times 2 \mathrm{~cm}$, membranáceas, elípticalanceoladas, ápice agudo a levemente acuminado, base aguda, camptódromas, nervação secundária com espaçamento irregular; pecíolo ca. $5 \mathrm{~mm}$ compr.; folhas estipuláceas aos pares, lanceoladas, recurvadas, ca. $1 \mathrm{~cm}$ compr., subsésseis. Flores isoladas ou ca. 2-4 fasciculadas, axilares ou no ápice dos ramos, subsésseis, bractéolas até $2 \mathrm{~mm}$ compr.; cálice tubuloso, levemente laciniado; corola ca. 2,2 cm compr., estreitoinfundibuliforme, amarelada, lacínias lanceoladas, papilosas, ca. $5 \mathrm{~mm}$ diâm; anteras orbiculares, filete $1,3 \mathrm{~cm}$ adnato ao tubo e 3 mm livre, geniculado, tricomas simples um tanto abaixo da inserção; estigma um pouco acima dos estames, capitado. Fruto não observado. 
Material examinado: trilha do Corisquinho, 150-200 m s.m., 26.IV.1997, fl., J. M. A. Braga et al. 3987 (RB, RUSU).

Distribuição geográfica: no Brasil, há registros para os estados do Acre, Rondônia, Região Sudeste e Paraná (Carvalho 1997a).

\section{Dyssochroma Miers}

14. Dyssochroma viridiflora (Sims) Miers, Ann. Mag. Nat. Hist., ser. 2 (4): 251. 1849. Fig. 4 a-c

Solandra viridiflora Sims, Bot. Mag. 45, tab. 1948. 1818.

Arbusto hemi-epífito escandente ou terrestre, glabro. Ramos flexuosos, esfoliantes, nodosos, cicatrizes foliares evidentes. Folhas isoladas, inteiras; lâminas até $14 \times 4,6 \mathrm{~cm}$, cartáceas, lanceoladas a levemente obovadas, ápice atenuado, base aguda, camptódromas, nervuras secundárias com espaçamento irregular, domáceas pilíferas na região das nervuras. Flores isoladas ou 2-3 em racemo com raque reduzida, pêndulas; pedicelo ca. 1 cm compr.; cálice campanulado, profundamente partido; corola ca. $4 \mathrm{~cm}$ compr., verdeclaro, infundibuliforme a hipocraterimorfa, lacínias lanceoladas, enroladas após a antese; anteras exsertas, lineares, ca. $1,8 \mathrm{~cm} \times 2 \mathrm{~mm}$, filetes concrescidos na região basal do tubo corolíneo, ca. $7 \mathrm{~cm}$ compr.; ovário alvacento, ca. $1 \mathrm{~cm} \times 4 \mathrm{~mm}$, com disco nectarífero anelar; estilete quase do mesmo tamanho dos estames; região estigmática apical. Baga ca. $4 \mathrm{~cm}$ compr., oblongo-apiculadas, lacínias do cálice patente - estreladas na frutificação, ca. 400 sementes.

Material examinado: trilha para a Lagoa Seca, 70-800 m s.m., 14.VIII.1999, fl. fr., $M$. G. Bovini et al. 1668 (RUSU); sobre árvore em beira de rio, 04.VIII.1994, fl., A. Costa et al. 458 (RUSU); trilha para o Poço do Rio Grande, 15.IX.1996, fl. fr., J. A. Lira Neto et al. 362 (RUSU)

Distribuição: ocorre nos estados de Minas Gerais, Rio de Janeiro e São Paulo (Carvalho 1997a).
Hemi-epífita encontrada na RRP quase sempre nas ramificações dos ramos de grandes árvores e, em estádio vegetativo, a visualização torna-se difícil. Encontrada na margem de rio e no interior da floresta.

Physalis L.

15. Physalis pubescens L. var. pubescens, Sp. pl.1: 183. 1753.

Erva a subarbusto ca. $30 \mathrm{~cm}$ alt. Ramos hialinos, tomentosos, tricomas simples e glândulares. Folhas inteiras, isoladas; lâminas até 4,2 × 3,2 cm, membranáceas, ovadas a cordadas, um tanto lobado-denteadas, ápice atenuado, base truncada a cordada, margem ciliada, campto-broquidódromas, nervuras secundárias com espaçamento diminuindo para a base, pubescente ao longo das nervuras, tricomas simples e glândulares; pecíolo ca. 2,5 $\mathrm{cm}$ compr. Flores isoladas, axilares; pedicelo ca. 2 mm compr.; cálice campanulado, lacínias lanceoladas; corola ca. $7 \mathrm{~mm}$ compr., amarela, rotáceo-denteada, tricomas simples na face externa; anteras oblongas, deiscência longitudinal lateral, filetes quase do mesmo tamanho das anteras amarelas; estigma mesma altura dos estames. Baga ca. 7 mm diâm., globosa, cálice ampliado, inflado, lacínias reunidas no ápice, envolvendo totalmente o fruto. Material examinado: trilha do cambucá, 200 m s.m., 17.VIII.1997, fl. fr., J. M. A. Braga et al. 3414 (RUSU); trilha para a Lagoa Seca, 100-550 m s.m., 12.VII.1997, fl. fr., M. G. Bovini et al. 1206 (RUSU).

Distribuição geográfica: Américas do Norte, Central e do Sul e regiões tropicais do Velho Mundo (Rojas \& Nessi 1998).

\section{Solanum L.}

16. Solanum alternatopinnatum Steud., Nomencl. Bot. 2, ed.2: 600. 1841. Fig. 4 d-f Escandente, herbáceo-lenhosa, acúleos uncinados, retrorsos, isolados ou aos pares, esparsos nos ramos, aplanado lateralmente, glabro. Folhas isoladas, pinatissectas, pseudoimparipenadas, 5-7 segmentos; lâminas até 15 $\times 3,5 \mathrm{~cm}$, membranáceas, base truncada a 
assimétrica, acúleos uncinados esparsos no pecíolo e ao longo das nervuras, broquidódroma e campto-broquidódroma, nervuras secundárias com espaçamento irregular; pecíolo ca. $4 \mathrm{~cm}$ compr.. Flores ca. 40, em corimbo dicotômico na porção terminal dos ramos, com acúleos uncinados e aciculares; botões turbinados; pedicelo ca. $1 \mathrm{~cm}$ compr., articulado; cálice campanulado, oblongodenteado, face interna papilosa; corola até 1,1 cm compr., alva, campanulado-estrelada, lacínias partidas, desiguais em compr., linearlanceoladas, ápice um tanto cuculado; anteras com poros apicais pequenos, atenuadas, introrsas; estilete duas vezes o tamanho dos estames, estigma apical. Baga ca. 2,2 cm diâm., globosa, verde variegada, quando madura amarela, cálice persistente, ca. 20 sementes. Material examinado: trilha para o Cambucá, 17.VIII.1996, fr., M. G. Bovini et al. 1011 (RB, RUSU); trilha para o Pico do Corisco, 600 m s.m., 25.III.2000, fl., M. G. Bovini et al. 1810 (RB, RUSU).

Distribuição geográfica: ocorre nos estados de Goiás, Bahia, Minas Gerais, Espírito Santo, Rio de Janeiro, São Paulo, Paraná e Santa Catarina extendendo-se até o Paraguai (Nee 1999).

Espécie heliófila de hábito escandente geralmente no dossel da floresta, por este motivo a visualização é muito difícil, pode ser facilitada pela presença de frutos maduros amarelados caídos no solo da floresta. O hábito e as folhas pinatissectas aculeadas, permitem identificar facilmente a espécie.

17. Solanum americanum Mill. var. nodiflorum (Jacq.) Edmonds, Journ. Arnold. Arb. 52: 634. 1971.

Subarbustos até $50 \mathrm{~cm}$ alt., ereta. Ramos pubescentes, tricomas simples e papilas. Folhas inteiras, isoladas ou aos pares; lâminas até 3,5 × 1,8 cm, membranáceas, ovado-lanceoladas, ápice acuminado, base um tanto decurrente, camptódromas, nervuras secundárias com espaçamento uniforme, pubescentes, em ambas as faces, tricomas simples; pecíolo até
1,6 cm compr., pubérulo. Flores 5-6, em pseudo-umbelas, extra-axilares, pedicelo até $5 \mathrm{~mm}$ compr., reflexos; cálice campanulado, denteado; corola ca. $2 \mathrm{~mm}$ compr., alva, rotáceo-estrelada, lacínias lanceoladas; anteras com poros apicais grandes, oblongas, introrsas, filete mais curto que as anteras; estigma mesma altura dos estames, região estigmática apical. Baga até $6 \mathrm{~mm}$ diâm., globosa, verdeclaro, nigrescente brilhante quando maduras, ca. 12 sementes.

Material examinado: trilha do Cambucá, 200300 m s.m., 15.IX.1996, fl.fr., M. G. Bovini et al. 1056 (RUSU).

Distribuição geográfica: ocorre em todo o território nacional, nos trópicos e subtrópicos do mundo (Nee 1999).

Encontrada em ambientes perturbados, onde forma grandes populações. Talvez seja a espécie de Solanum mais frequente em número de indivíduos (Nee 1999). Em outras áreas já foi encontrada em altitudes acima de $1.000 \mathrm{~m} \mathrm{~s} . \mathrm{m}$.

18. Solanum argenteum Dunal, Encycl. Méth., Bot. Suppl. 3(2): 755. 1814.

Arvoreta 2-3 m alt. Ramos aplanados na região terminal, esfoliante, indumento prateado, adpresso, tricomas peltados, peltadoestrelados. Folhas inteiras, isoladas ou aos pares; lâminas até $18 \times 6 \mathrm{~cm}$, cartáceas, lanceolada, ápice agudo, base aguda, broquidódromas, nervação secundária com espaçamento uniforme, face adaxial glabra, face abaxial lepidoto-adpressa, alvacenta a prateada, tricomas peltados e peltadoestrelados; pecíolo ca. $2 \mathrm{~cm}$ compr. Flores $2-$ 7, cimeiras simples, escorpioides, axilares; pedicelo $5 \mathrm{~mm}$ compr.; cálice campanulado, lacínias agudas; corola ca. $7 \mathrm{~mm}$ diâm., alva, rotáceo-estrelada, lacínias lanceoladas; anteras com poros apicais grandes, oblongas, introrsas, filetes menores que as anteras, estigma acima das anteras. Baga ca. 2,5 cm diâm., oblonga apiculadas, nigrescente, tricomas estrelados, esparsos, ca. 32 sementes. 

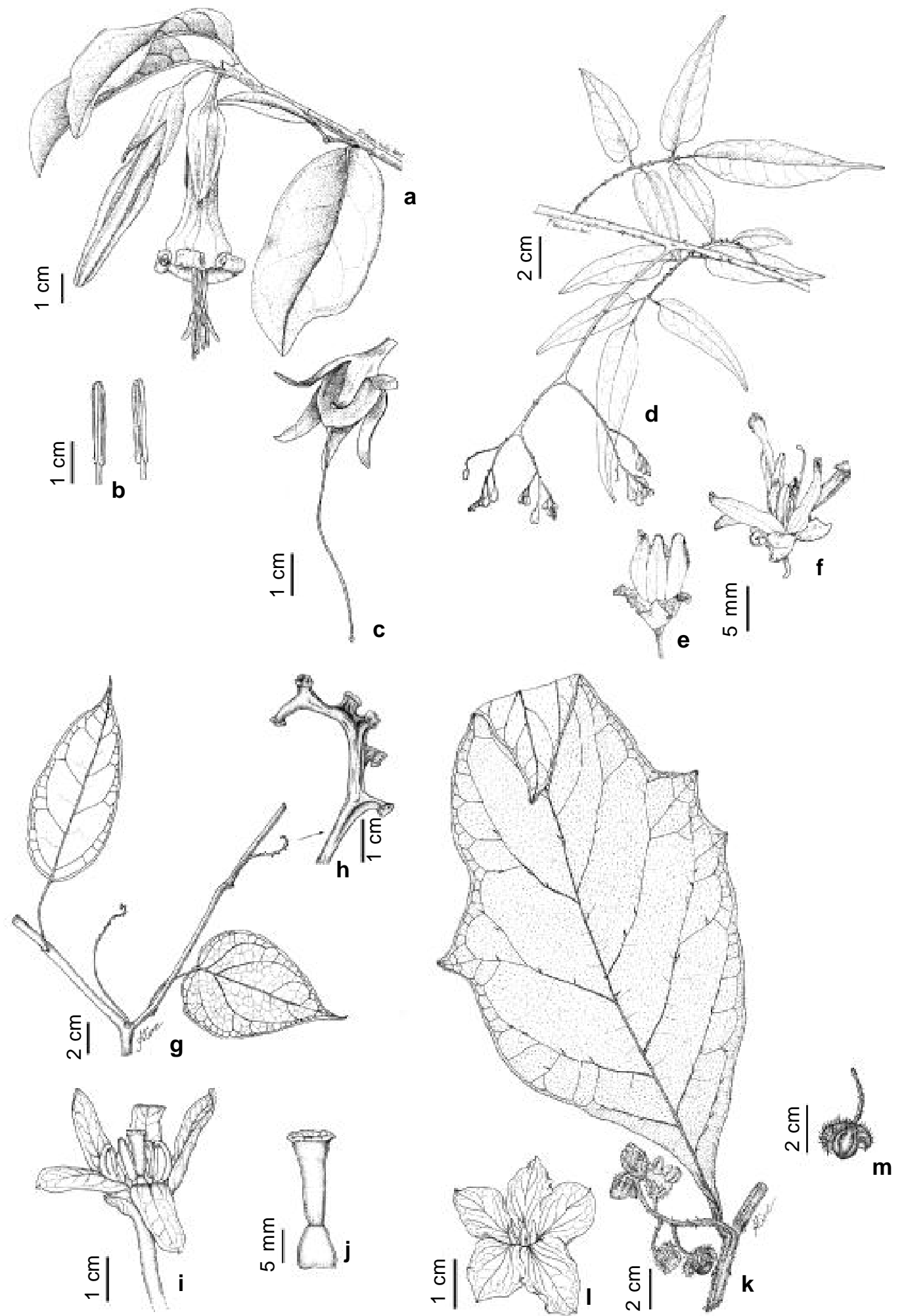

Figura 4 - Dyssochroma viridiflora. a. ramo com flores; b. anteras lineares; c. fruto (Bovini 1668). Solanum alternatopinnatum. d. ramo com flores; e. botão; f. flor (Bovini 1810). Solanum diploconos. g. ramo com a raque da inflorescência; h. detalhe da raque; i. flor; j. gineceu (Bovini 1113). Solanum hexandrum. k. ramo com flores; 1. relação corola/estames; m. fruto (Bovini 1072). 
Material examinado: trilha do Cambucá, 200300 m s.m., 14.IX.1996, fr., M. G. Bovini et al. 1051 (RUSU).

Distribuição geográfica: Ocorre nos estados do Pará, Bahia, Goiás, Região Sudeste e Paraná (Carvalho 1997b).

Arvoreta muito freqüente, principalmente na floresta pluvial atlântica, de fácil reconhecimento por apresentar na face adaxial das lâminas foliares indumento prateado. Na RRP foi muito comum nas margens de trilhas semiheliófilas formando grandes populações.

19. Solanum capsicoides All., Auct. Syn. Meth. Strip. Hort. Reg. Taurensis 64. 1773.

Nome vulgar: arrebenta-cavalo

Erva até $5 \mathrm{~mm}$ alt. Ramos concaulescentes com pontuações alvacentas, aculeados, aciculares, até $8 \mathrm{~mm}$ compr., reflexos, tricomas simples longos, às vezes do tamanho dos acúleos. Folhas inteiras isoladas; lâminas até $20 \times 16 \mathrm{~cm}$, membranáceas, deltóides, irregular-partidas, segmentos lobados, base truncada, acúleos aciculares ao longo das nervuras, camptódromas, nervação secundária com espaçamento irregular, tricomas simples longos, esparsos em ambas as faces; pecíolo ca. $10 \mathrm{~cm}$ compr., acúleado, tricomas simples esparsos. Flores 4-5, cimeiras; pedicelo ca. $9 \mathrm{~mm}$ compr., tricomas simples maiores que os acúleos aciculares; cálice campanulado; corola ca. $9 \mathrm{~mm}$ compr., alva, rotáceo-estrelada, lacínias lanceoladas; anteras com poros apicais pequenos, atenuadas, filetes menores que as anteras. Fruto não observado. Material examinado: trilha do Cambucá, 200300 m s.m., 14.IX.1996, fl., M. G. Bovini et al. 1033 (RUSU).

Distribuição geográfica: ocorre da América Central até o Brasil; introduzidas no velho mundo (Nee 1999).

20. Solanum castaneum Carv., Pesquisas, Bot. 46: 19. 1996.

Arbusto até $5 \mathrm{~m}$ alt. Ramos com indumento acastanhado, lepidoto-tomentoso, tricomas estrelados, longo-pedicelados e paleáceo-fimbriados. Folhas isoladas, inteiras; lâminas $60 \times 32 \mathrm{~cm}$, cartáceas, ovados a ovado-lanceoladas, ápice atenuado, base aguda, camptódromas, nervação secundária com espaçamento uniforme; face adaxial verde, glabrescente, bulada e face abaxial alvacenta a acastanhada, lepidoto-tomentosa, tricomas peltado-apiculados, pedicelados e tricomas paleáceos ao longo das nervuras secundárias basais; pecíolo até $10 \mathrm{~cm}$ compr., alvacento a acastanhado, denso-paleáceo. Flores ca. 20, em racemos dicotômicas, até 8 ramos; pedicelo ca. $5 \mathrm{~mm}$ compr.; cálice urceolado, denso-tomentoso, lacínias agudas; corola ca. 1,5 cm compr., alva, rotáceoestrelada, lacínias agudas, anteras oblongas, introrsas, poros apicais grandes, abrindo-se por fendas longitudinais, filetes menores que as anteras, estigma acima dos estames. Baga ca. $1,2 \mathrm{~cm}$ diâm., globosa, envolvidas pelo cálice ampliado, ca. 34 sementes.

Material examinado: trilha do Cambucá, 20.X.1996, fr., J. A. Lira Neto et al. 448 (RUSU).

Distribuição geográfica: ocorre nos estados de Minas Gerais, Rio de Janeiro, São Paulo e Paraná (Carvalho 1997b).

É comum em floresta pluvial atlântica e floresta de araucária. As folhas grandes com indumento acastanhado, lepidoto-tomentoso e muitas vezes com tricomas paleáceos, torna fácil a visualização desta espécie na floresta. Comum em beira de trilhas, mas em locais semi-heliófilos.

21. Solanum diploconos (Mart.) Bohs., Taxon 44: 584. 1995.

Fig. 4 g-j

Witheringia diploconos Mart., Nov. Gen. Sp. Pl. 3: 76. tab. 229. 1829.

Arbusto escandente. Ramos dicotômicos, flexuosos, glabros. Folhas inteiras, isoladas; lâminas até $16 \times 7 \mathrm{~cm}$, membranáceas a cartáceas, ovado-oblongas a cordadas, ápice acuminado-falcado, base assimétrica, camptódromas, nervação secundária com espaçamento irregular, evidente a presença de hidatódio, tricomas simples ao longo da nervura 
mediana, pecíolo até $6 \mathrm{~cm}$ compr. Flores $15-$ 27 , em cimeiras simples, extra-axilar ou na dicotomia dos ramos, pedicelo ca. 2,5 cm compr., articulado próximo à base e por isso residual na raque; botões turbinados; cálice campanulado, laciniado; corola ca. 3 cm diâm., amarelada, campanulado-estrelada, lacínias lanceoladas reflexas e espessadas no ápice; anteras atenuadas, ca. $5 \mathrm{~mm}$ compr., filete menor que as anteras, conectivo vinoso, giboso, mais espessado na região basal; estilete espesso, ca. $5 \mathrm{~mm}$ compr., estigma expandido acima dos estames, corpúsculos globosos no interior. Fruto não observado.

Material examinado: trilha do Cambucá, 200300 m s.m., 30.XI.1996, fl., M.G.Bovini et al. 1113 (RB, RUSU).

Distribuição geográfica: ocorre nos estados das Regiões Sudeste e Sul do Brasil (Bohs 1994).

22. Solanum hexandrum Vell., Fl. Flum. Icon. 2, t. 122 (1827) 1831, text. in Arch. Mus. Nac. Rio de Janeiro 5: 88. 1881. Fig. 4 k-m

Arbusto ca. 3 m alt.. Ramos aplanados na região terminal, híspidos, tricomas estrelados pedicelados, espessos acúleos de aciculares a uncinados de base aplanada, esparsos. Folhas inteiras, isoladas; lâminas até $42 \times 22 \mathrm{~cm}$, membranáceas, assimétricas, largo-lanceoladas, base decurrente, ápice obtuso, margem lobadodenteada, camptódromas, nervuras secundárias com espaçamento diminuindo para a base, híspida, tricomas espessos, estrelado-pedicelados em ambas as faces; pecíolo até $3,5 \mathrm{~cm}$ compr., híspido. Flores ca. 12, em cima-escorpióide; pedicelo ca. $2 \mathrm{~cm}$ compr., articulado; cálice campanulado, lacínias ovado-agudas, híspidas, acúleos aciculares; corola ca. $8 \mathrm{~cm}$ diâm., violácea, rotáceo-lobada, lacínias oblongas, glabras na face interna e na face externa, tricomas estrelados esparsos na região das nervuras; anteras com poros apicais pequenos, atenuadas, desiguais em tamanho, ca. $1 \mathrm{~cm}$ compr., filetes menores que as anteras, estigma acima dos estames. Baga ca. 1,2 cm diâm., globosa, ca., glabras, envolvida pelo cálice ampliado; ca. 70 sementes.
Material examinado: trilha do Cambucá, 200300 m s.m., 19.X.1996, fl., M. G. Bovini et al. 1072 (RB, RUSU); trilha para a Toca da Aranha, 250 m s.m., 29.IX.1998, fl.fr., $R$. $C$. Lopes et al. 109 (RUSU).

Distribuição geográfica: ocorre nos estados da Bahia, Minas Gerais, Rio de Janeiro e São Paulo (Carvalho 1997b).

Espécie facilmente reconhecida pelo indumento híspido, enorme quantidade de acúleos e pelas flores vistosas e violáceas. Exclusiva de floresta pluvial atlântica é restrita ao estado da Bahia e Região Sudeste, muito comum em áreas semi-heliófilas e levemente descampadas.

23. Solanum hirtellum (Spreng.) Hassl., Feddes Repert. Spec. Nov. Regni Veg. Beih. 15:218. 1918. Fig. $5 \mathrm{a}, \mathrm{b}$ Atropa hirtella Spreng., Syst. Veg. 1: 699. 1825.

Arbusto ca. $4 \mathrm{~m}$ alt. Ramos flexuosos, cilíndricos, pubérulos, hialinos. Folhas isoladas ou aos pares, desiguais, inteiras; lâminas até $11,5 \times 4,5 \mathrm{~cm}$, membranáceas, lanceoladas, ápice atenuado a cuspidado, base assimétrica, camptódromas, nervação secundária com espaçamento aumentando em direção ao ápice, áspera em ambas as faces, tricomas estrelados sésseis ao longo das nervuras; pecíolo ca. 5 mm compr.. Flores ca. 20, em cimeira dicotômica laxa, extra-axilar, articuladas na base; pedicelo ca. $2 \mathrm{~mm}$ compr.; cálice campanulado, tricomas estrelados apiculados, lacínias agudas; corola até $3 \mathrm{~mm}$ compr., alva, rotáceo-estrelada, lacínias lanceoladas; anteras com poros apicais grandes, oblongas, sésseis, introrsas; estigma mesma altura ou pouco acima dos estames. Baga ca. 6 mm diâm., globosa, ca. 6 sementes.

Material examinado: trilha o Cambucá, 200300 m s.m., 30.XI.1996, fl. fr., M. G. Bovini et al. 1109 (RB, RUSU).

Distribuição geográfica: ocorre nos estados das Regiões Sudeste e Sul do Brasil e Paraguai e Argentina (Mentz \& Oliveira 2004). 
24. Solanum martii Sendtn., in Martius, Fl. bras. 10:41. tab. 10. 1846.

Nome vulgar: açucena

Arbusto ca. $3 \mathrm{~m}$ alt. Ramos cilíndricos, glabros. Folhas isoladas, inteiras; lâminas até $30 \times 16 \mathrm{~cm}$, membranáceas, ovado-lanceoladas, , ápice acuminado, base truncada-aguda, camptódromas, nervação secundária com espaçamento irregular, glabrescentes na face ventral, tricomas estrelados sésseis esparsos ao longo da nervura principal, tomentosoacastanhado com tricomas estreladopedicelados na face abaxial; pecíolo ca. 3,5 cm compr., tomentoso-acastanhado. Flores ca. 7, em cimeiras congestas, reflexa, tomentosaacastanhada; pedicelo ca. $2 \mathrm{~mm}$ compr., tomentoso; cálice campanulado, tomentosoacastanhado, lacínias agudas; corola ca. $7 \mathrm{~mm}$ compr., alva, rotáceo-estrelada, lacínias lanceoladas, tomentosas na face externa; anteras com poros apicais grandes, abrindose por fendas longitudinais, oblongas, sésseis, introrsas; estigma acima dos estames. Fruto não observado.

Material examinado: trilha da Toca da Aranha, 04.XI.1997, fl., R. H. P. Andreata et al. 1015 (RB, RUSU).

Distribuição geográfica: ocorre nos estados de Minas Gerais, Rio de Janeiro e São Paulo (Carvalho 1997b).

25. Solanum melissarum Bohs, Taxon 44: 584. 1995.

Witheringia divaricata Mart., Nov. Gen. sp. pl. 3:75. tab. 228. 1829.

Arbusto ereto à escandente. Ramos dicotômicos, flexuosos, glabros. Folhas inteiras, isoladas; lâminas até $17 \times 8 \mathrm{~cm}$, membranáceas a cartáceas, ovadas a lanceoladas, ápice acuminado a falcado, base assimétrica, decurrente, truncada, camptódromas, nervação secundária com espaçamento irregular; tricomas glandulares diminutos; pecíolo até 3 cm compr. Flores ca. 15, em cimeiras simples, extra-axilar, pedúnculo ca. $10 \mathrm{~cm}$ compr., pedicelo articulado próximo a base e por isso residual na raque; botões turbinados; cálice campanulado, laciniado; corola ca. 2,5 cm diâm., alva a vinosa, campanulado-estrelada, lacínias lanceoladas, reflexas,; anteras atenuadas, ca. $9 \mathrm{~mm}$ compr., filete menor que as anteras, conectivo vinoso, giboso, mais espessado na região basal; estilete pouco espesso, ca. $9 \mathrm{~mm}$ compr., estigma expandido pouco acima dos estames. Fruto não observado. Material examinado: trilha do Cambucá, 70310 m s.m., 23.XI.1999, fl., M. G. Bovini et al. 1719 (RB, RUSU).

Distribuição geográfica: ocorre nos estados do Pará, Paraíba, Bahia, Região Sudeste e Santa Catarina (Bohs 1994).

26. Solanum odoriferum Vell., Fl. Flum. Icon 2, t. 108 (1827) 1831; text. in Arch. Mus. Nac. Rio de Janeiro 5: 60. $1881 . \quad$ Fig. 5 c-g Arbusto escandente. Ramos angulosos, levemente estriados. Folhas inteiras, isoladas nos ângulos ramulares; lâminas até $12,5 \times 5 \mathrm{~cm}$, cartáceas, ovado-lanceoladas, ápice atenuado, base truncada, margem revoluta, camptobroquidódromas, nervuras secundárias com espaçamento irregular; pecíolo ca. $2,5 \mathrm{~cm}$ compr. Flores ca. 45 flores, em cimeiras dicotômicas na porção terminal dos ramos; pedicelo ca. 1,8 cm compr., dilatado na porção basal, articulado; botões oblongo-apiculados; cálice campanulado, ápice truncado; corola alva, até $8 \mathrm{~mm}$ compr., rotáceo-estrelada, lacínias lanceoladas; anteras com poros apicais grandes, oblongas, introrsas; filetes um pouco mais curtos que as anteras; estigma acima dos estames. Baga ca. $8 \mathrm{~mm}$ diâm., globosa, ca. 9 sementes.

Material examinado: subindo o Rio Grande a partir da trilha para o Corisquinho, margem direita, 7.IV.1999, fl.fr., C. H. R. Paula et al. 123 (RUSU); margem do Rio Grande, 19.VIII.1996, fl. fr., J. A. Lira Neto et al. 319 (RUSU).

Distribuição geográfica: ocorre nos estados do Rio de Janeiro, São Paulo, Paraná e Santa Catarina (Carvalho 1997b).

Espécie caracterizada pelos ramos em "zig-zag" e quando com frutos, os ramos tornam-se ainda mais pendentes, talvez pelo peso das bagas. Na RRP apresenta-se sempre em indivíduos isolados.

Rodriguésia 57 (1): 75-98. 2006 

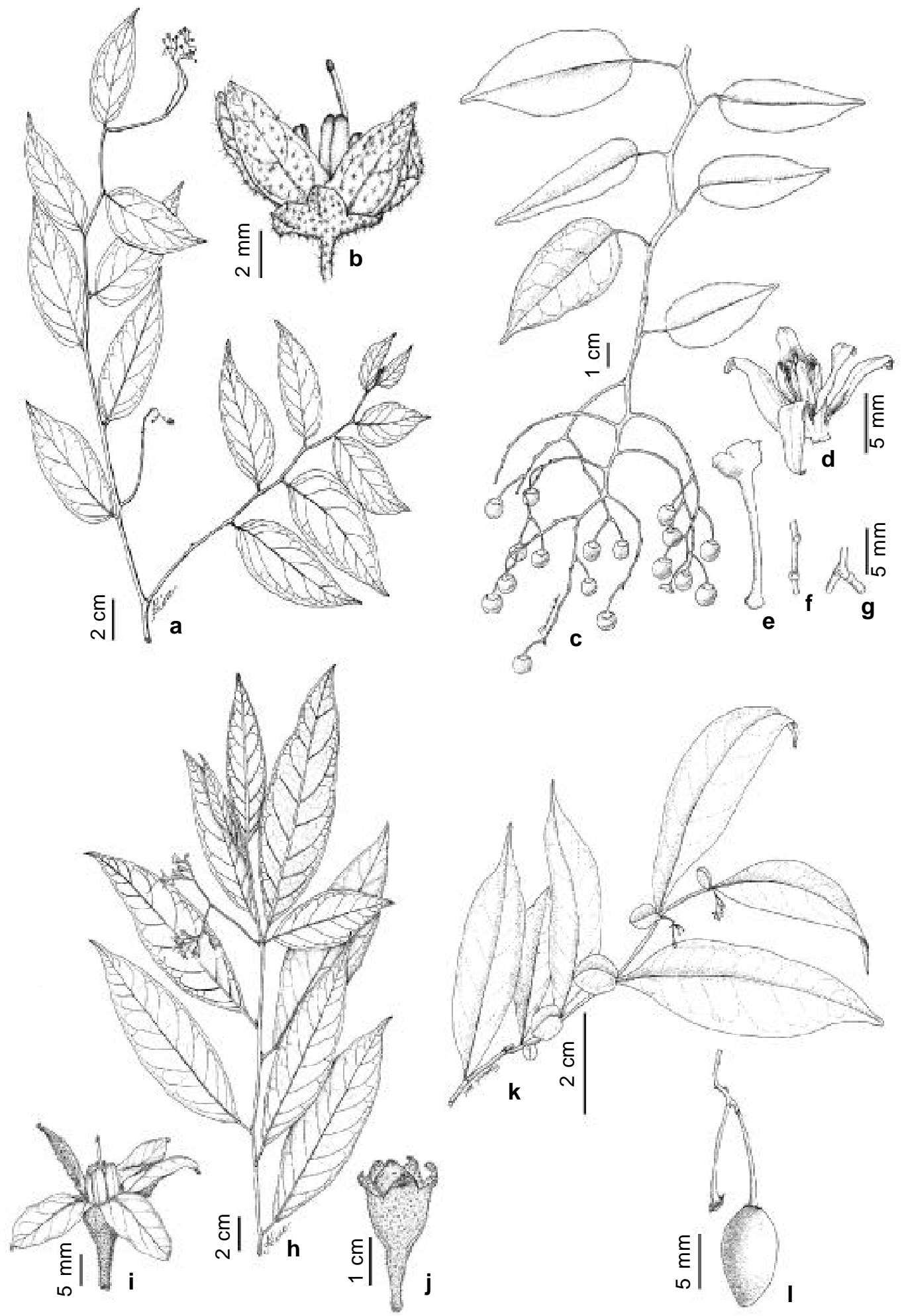

Figura 5 - Solanum hirtellum. a. ramo com flores; b. flor (Bovini 1109). Solanum odoriferum. c. ramo com frutos; d. flor; e. pedicelo dilatado na porção basal; f. cicatrizes; g. articulações; (Lira Neto 319). Solanum rufescens. h. ramo com flores; i. flor; j. fruto com cálice acrescente (Brade 18762). Solanum stipulatum. k. ramo com flores; 1. fruto (Lira Neto572). 
27. Solanum paralum Bohs, Taxon 44: 585. 1995.

Arbusto ereto a escandente. Ramos dicotômicos, glabros. Folhas inteiras ou pinatissectas, isoladas; lâminas até $18 \times 8 \mathrm{~cm}$, quando inteiras membranáceas, ovadas, oblongas ou lanceoladas, ápice acuminado, às vezes levemente falcado, base assimétrica, decurrente, truncada ou cuneada, camptódromas, nervação secundária com espaçamento irregular, tricomas glandulares diminutos, esparsos na face abaxial; pecíolo até 7,0 cm compr.; lâminas quando pinatissectas 3-segmentos, lanceolados; pecíolo ca. 5,0 cm compr. Flores 15-25, em cimeiras simples ou dicotômicas, extra-axilares, pedúnculo ca. 3,0 cm compr., pedicelo articulado próximo à base e por isso residual na raque; botões oblongos a turbinados; cálice campanulado, laciniado; corola ca. 2,0 cm diâm., alvo-esverdeada a vinosa, campanulado-estrelada, lacínias lanceoladas; anteras atenuadas, ca. $0,4 \mathrm{~cm}$ compr., filete menor que as anteras, conectivo vinoso, giboso; estilete ca. $0,5 \mathrm{~cm}$ compr., estigma expandido pouco acima os estames. Fruto não observado.

Material examinado: trilha para a Toca da Aranha, 24.XI.1998, fl., M. G. Bovini 1586 et J. M. A.Braga (RUSU); idem, $400 \mathrm{~m}$ s.m., 24.XI.1998, fl., M. G. Bovini 1589 et J. M. A. Braga (RB, RUSU); trilha da Toca da Aranha, 21.X.1997, fl., J. M. A. Braga et al. 4346 (RB, RUSU).

Distribuição geográfica: nos estados da Bahia, Rio de Janeiro e São Paulo (Bohs 1994).

28- Solanum pensile Sendtn., in Mart., Fl. bras. 10:50. tab. 4. 1846.

Fig. 6

Escandente. Ramos estriados, glabros. Folhas inteiras, isoladas, esparsas; lâminas até $12 \times 5,5 \mathrm{~cm}$, membranáceas a cartáceas, ovadolanceoladas, ápice agudo, base obtusa, camptódromas, nervação secundária com espaçamento uniforme; pecíolo ca. $4 \mathrm{~cm}$ compr. Flores 20-30, em cimeiras dicotômicas, terminal; botões oblongos; pedicelo ca. $1,2 \mathrm{~cm}$ compr.; cálice campanulado, denteado; corola ca. $1 \mathrm{~cm}$ compr., alva a lilás, rotáceo-estrelada, lacínias lanceoladas; anteras com poros grandes, oblongas, abrindo-se por fendas longitudinais, subsésseis, filetes pouco mais curtos que as anteras; estigma pouco mais acima dos estames. Fruto não observado.

Material examinado: trilha para o Corisquinho, 31.XI.1996, fl., J. A. Lira Neto et al. 504 (RB, RUSU).

Material adicional: BRASIL. ACRE: Plácido de Castro, km 20, 5.II.2000, fl., I. S. Rivero et al. 355 (INPA); AMAZONAS: Esperança, terra firme baixa, 7.II.1942, fl. fr., A. Ducke 3375 (RB); idem, Rio Negro, Santo Antonio, Igapó, 8.VIII.1991, fl. fr., S. Mori et al. 21971 (INPA); PARÁ: Belém, Terra Firme, 13.I.1953, fl.fr., J. M. Pires et al. 4435 (IAN); RIO DE JANEIRO: Nova Friburgo, distr. Macaé de Cima, ca. 1.000 m s.m., 08.XII.1989, bt. fl., B. Kurtz et al. 86 (RB).

Distribuição geográfica: ocorre nos estados do Amazonas, Pará e Rio de Janeiro; fora do Brasil foi registrada também nas Guianas Inglesas (Sendtner 1846).

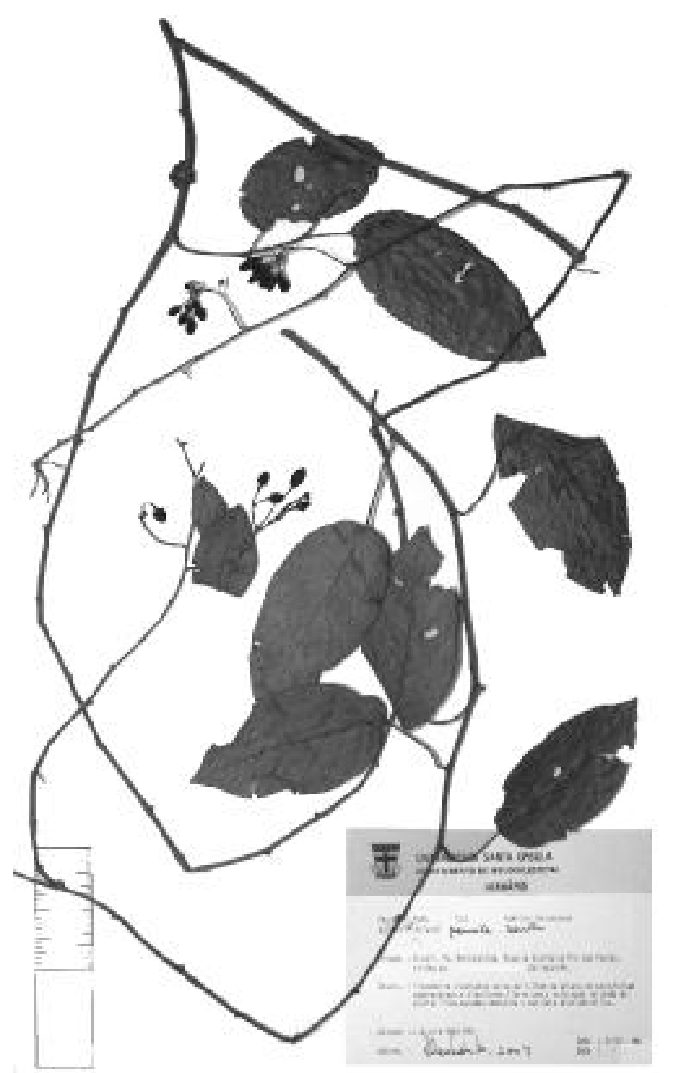

Figura 6 - Solanum pensile: ramo com flores (Lira Neto 504) 
Após várias consultas em bibliografias especializadas, concluiu-se que para a espécie em questão, esta é primeira divulgação de ocorrência para o estado, anteriormente conhecida apenas para a região amazônica. É caracterizada pelos ramos retos e botões oblongos, diferenciando-se com isso de $S$. odoriferum.

29. Solanum pseudoquina A.St. -Hil., Pl. Usuel. Bres., part 5: 1. tab. 21. 1825.

Nome vulgar: caixeta

Árvore até $10 \mathrm{~m}$ alt.. Ramos esfoliantes, lenticelados, geralmente amarelados. Folhas aos pares, inteiras; lâminas até $13 \times 5 \mathrm{~cm}$, cartáceas, desiguais em tamanho, lanceoladas, ápice apiculado, base decurrente, camptódroma, nervação secundária com espaçamento uniforme, amareladas depois de seca, domáceas pilíferas na axila das nervuras secundárias; pecíolo canaliculado, ca. $1,5 \mathrm{~cm}$ compr. Flores 10-20 flores, em cimeiras simples ou dicotômica; pedicelo ca. $1 \mathrm{~cm}$ compr., articulado; cálice campanulado, lacínias truncadas; corola ca. 0,8 cm diâm., alva, rotáceo-estrelada, lacínias lanceoladas; anteras dimorfas, 3 maiores com poros apicais grandes, abrindo-se por fendas longitudinais e 2 menores com poros apicais pequenos, oblongas; estigma clavado pouco acima dos estames. Baga globosa, ca. 1,5 diâm., verde escuro quando maduras; ca. 60 sementes. Material examinado: trilha das Borboletas, margem de rio, 1.III.1997, fr., M. G. Bovini \& J.M. A. Braga 1140 (RUSU); idem, 9.I.1998, fr., M. G. Bovini \& J. M. A. Braga 1266 (RUSU); trilha para a Toca da Aranha, 23.XI.1998, fl., M. G. Bovini \& J. M. A. Braga 1568 (RUSU); trilha para o Pico do Corisco, 710 m s.m., 25.III.2000, fr., M. G. Bovini et al. 1815 (RB, RUSU).

Distribuição geográfica: nos estados das Regiões Sudeste e Sul do Brasil (Knapp 2002).

Talvez seja a única espécie de Solanaceae que alcança o dossel na RRP. Ocorre às vezes em grandes populações. Suas características morfológicas marcantes são as nervuras amareladas quando herborizadas. Conhecida como $S$. inaequale, a qual foi sinonimizada por Knapp (2002).
30. Solanum rufescens Sendtn., in Mart., Fl. bras. 10: 39. 1846.

Fig. 5 h-j

Arbusto ca. $1 \mathrm{~m}$ alt. Ramos castanhotomentosos; gemas foliares frequentes. Folhas isoladas e aos pares, inteiras; lâminas até $25 \times$ $6 \mathrm{~cm}$, cartáceas, lanceoladas, ápice levemente acuminado, base obtusa a aguda, camptódromas, nervação secundária com espaçamento uniforme, face adaxial com tricomas estrelados sésseis e pedicelados ao longo da nervura principal, face abaxial acastanhado, tomentosa, tricomas hialinos; pecíolo ca. 2,4 cm compr. Flores 25-35 em cimeiras dicotômicas, opositifolia; pedicelo ca. $6 \mathrm{~mm}$ compr.; cálice campanulado, lacínias agudas; corola ca. 1,5 cm compr., alva, campanulado-estrelada, lacínias lanceoladas, face externa denso-tomentosa; anteras com poros apicais grandes, abrindose por fendas longitudinais, oblongas, introrsas, filetes menores que as anteras; estigma acima dos estames. Baga ca. 1 cm diâm., globosa, , cálice ampliado, ca. 25 sementes.

Material examinado: trilha para a toca da aranha, 26.X.2001, fl., M. G. Bovini et al. 2088 (RUSU).

Material adicional: BRASIL. RIO DE JANEIRO: Nova Friburgo, 12.X.1947, fl. fr., A. Brade 18762 (RB).

Distribuição geográfica: ocorre nos estados da Região Sudeste, Paraná e Santa Catarina (Mentz \& Oliveira 2004).

31. Solanum stipulatum Vell., Fl. Flum. Icon. 2. t. 117. (1827) 1831. text. in Arch. Mus. Nac. Rio de Janeiro 5: 87.

Fig. $5 \mathrm{k}, 1$

Arbusto até $2 \mathrm{~m}$ alt.. Ramos levemente sinuosos. Folhas inteiras aos pares, desiguais em tamanho e forma, glabras; lâminas as maiores até $14 \times 4 \mathrm{~cm}$, membranáceas, subsésseis, lanceoladas, assimétricas, as menores ca. $2 \mathrm{~cm}$ $\times 1,5 \mathrm{~cm}$, oblongo a orbiculares, ápice acuminado, base decurrente, margem ondulada, camptobroquidódromas, nervação secundária com espaçamento irregular. Flores 4-5, em cimeiras, opositifolias; pedicelo até $4 \mathrm{~mm}$ compr, articulado; botões turbinados; cálice campanulado, lacínias obtusas; corola ca. $3 \mathrm{~mm}$ compr., alva, campanulada, lacínias partidas; 
anteras com poros apicais grandes, abrindose por fendas longitudinais, oblongas, introrsas; estigma clavado, acima dos estames. Baga 6 mm diâm., piriforme, quando maduras alvas; cálice reflexo, persistente, ca. 4 sementes.

Material examinado: trilha para a Toca da Aranha, 200 m s.m., 11.I.1999, fl., M. G. Bovini et al. 1611 (RB, RUSU); trilha para a Lagoa Seca, 300-400 m s.m., 27.V.1997, fr., J. A. Lira Neto et al. 572 (RB, RUSU).

Distribuição geográfica: ocorre nos estados do Rio de Janeiro, São Paulo, Paraná e Santa Catarina (Mentz \& Oliveira 2004).

Subarbusto ciófilo ocorrendo sempre no estrato herbáceo-arbustivo em floresta pluvial atlântica. Na RRP, foi comum como indivíduos isolados.

32. Solanum swartzianum subsp. swartzianum var. swartzianum, Roem. \& Schult., Syst. Veg. Curant 4:602. 1819.

Árvore até $5 \mathrm{~m}$ alt. Ramos angulosos ou aplanados nas extremidades, indumento prateado, às vezes dourado-claro, lepidoto-adpresso, tricomas peltados e peltados-estrelados. Folhas isoladas ou aos pares, inteiras; lâminas até 14 $\times 5 \mathrm{~cm}$, cartáceas, lanceoladas à oblongas, ápice agudo a falcado, base atenuada, camptobroquidódromas, nervação secundária com espaçamento irregular, face adaxial esparsolepidoto, face abaxial lepidoto-adpresso, tricomas peltados; pecíolo ca. 1,6 cm compr. Flores 10-20, em cimeiras dicotômicas, eretos, opositifolia; pedicelo ca. $5 \mathrm{~mm}$ compr.; cálice campanulado, lacínias agudas; corola ca. $2 \mathrm{~cm}$ compr., alva, rotáceo-estrelada, lacínias lanceoladas; anteras com poros apicais grandes, oblongas, introrsas, filetes menores que as anteras; estigma acima dos estames. Baga ca. $1,3 \mathrm{~cm}$ diâm., globosa, cálice ampliado, envolvendo parcialmente o fruto, ca. 30 sementes. Material examinado: proximidades do Poço do Rio Grande, 80 m s.m., 23.III.1997, fl. fr., J. M. A. Braga et al. 3941 (RUSU); trilha do Cambucá, 20.X.1996, fl.fr., J. A. Lira Neto et al. 446 (RUSU).
Distribuição geográfica: ocorre nos estados de Roraima, Bahia, Região Sudeste, Paraná e Santa Catarina (Carvalho 1997b).

Espécie caracterizada pelo cálice frutífero persistente e quando o fruto está maduro, este o envolve quase que totalmente. Esta diferença e a forma do fruto a diferencia de S. argenteum. Ocorre sempre no subdossel de floresta pluvial atlântica, às vezes em grandes populações.

33. Solanum tabacifolium Dunal, in DC., Prodr. 13(1): 261. 1852 (non Vell.).

Arbusto ca. 2,5 m alt. Ramos esparsoaculeados, uncinados retrorsos, tricomas estrelados, sésseis, esparsos. Folhas isoladas; lâminas até $20 \times 18 \mathrm{~cm}$, membranáceas, lobadas, denteadas, desiguais na forma, deltóides a ovado-lanceoladas, ápice agudo, base assimétrica, truncada ou subcordada, craspedódromas, nervação secundária com espaçamento irregular, face adaxial híspida, tricomas estrelados sésseis e face abaxial tomentosa, tricomas estrelados sésseis e pedicelados, acúleos aciculares esparsos ao longo das nervuras; pecíolo ca. $5 \mathrm{~cm}$ compr., acúleos aciculares, tomentoso. Flores 20, em cimeiras dicotômicas, ca. $9 \mathrm{~mm}$ compr., nos entre nós foliares ou terminais; pedicelo até 1 cm compr., articulado; cálice campanulado, lacínias aciculares; corola ca. 1,2 cm compr., alva, campanulada-estrelada, tomentosa na face externa; anteras desiguais, com poros apicais pequenos, atenuadas, filete mais curto que as anteras; estigma um pouco acima dos estames. Fruto não observado.

Material examinado: trilha logo na entrada da Reserva, perto do portão, 15.IX.1996, fl., J. A. Lira Neto et al. 397 (RUSU).

Distribuição geográfica: ocorre nos estados da Bahia, Goiás, Mato Grosso, Minas Gerais, Rio de Janeiro, São Paulo, Paraná e Santa Catarina (Nee 1999).

Espécie ocorrente de áreas alteradas. Conhecida como $S$. torvum var. brasiliensis, foi sinonimizada por Nee (2001), e ainda sugerido pelo mesmo um nome novo, inédito, S. scuticum. 


\section{Agradecimentos}

À Fundação de Amparo a Pesquisa do Estado do Rio de Janeiro pelas bolsas concedidas aos ilustradores Paulo Ormindo e Aline S. de Oliveira; a coordenadora do Projeto Flora vascular da Reserva Rio das Pedras, Profa. Dra. Regina H. P. Andreata pelo convite; à bióloga Marta Moraes pela versão do resumo em inglês e à pesquisadora Karen L.G. De Toni pelo auxílio na confecção das estampas.

\section{REFERÊNCIAS BIBLIOGRÁFICAS}

Barbosa, G. E. \& Hunziker, A. T. 1989. Estudios sobre Solanaceae XXIX. Sinopsis taxonomia de Athenaea. Boletin Sociedad Argentina Botanica 26(1-2): 91-105.

Bohs, L. 1994. Cyphomandra (Solanaceae). Flora Neotropica Monograph 63: 1-176.

Carvalho, L. d'Á F. 1997a. Diversidade taxonômica das Solanáceas no estado do Rio de Janeiro (Brasil) - I. Albertoa 4(19): 245-260.

1997b. Diversidade taxonômica das Solanáceas no estado do Rio de Janeiro (Brasil) - II. Albertoa 4(21): 281-300.

\& Bovini, M. G. 1995. Aureliana

darcyi, a new species of Solanaceae from Brazil. Novon 5: 257-258.

; Costa, L. H. P. \& Duarte, A. C., 2001. Diversidade taxonômica e distribuição geográfica das Solanáceas que ocorrem no sudeste brasileiro (Acnistus, Athenaea, Aureliana, Brunfelsia, e Cyphomandra) Rodriguésia 52(80): 31-45.

Holmgren, P. K.; Keuken, W. \& Schofield, E. K. 1990. Index herbariorum, Part 1: The Herbaria of the World. $8^{\circ}$ ed., New York, New York Botanical Garden, 693p.

Hunziker, A. T. 1982. Estudios sobre Solanaceae XXII. Revision sinoptica de Acnistus. Kurtziana 5: 8-102.

2001. Genera Solanacearum. Eds. A. R. G. Gautner Verlag, Germany. 136 il. 500p.
\& Barboza, O. E. 1991. Estudios sobre Solanaceae XXX. Revision de Aureliana. Darwiniana 30(1-4): 95-113.

Knapp, S. 2002. Solanum section geminata (Solanaceae). Flora Neotropica Monograph 84: 1-405.

Leaf Architecture Working Group. 1999. Manual of Leaf Architecture: morphological description and categorization of dicotyledonous and net-veined monocotyledonous angiosperms. Washington, DC: Smithsonian Institution. Disponível também: http://www.peabody.yale.edu/ collections/pb/MLA/M.

Mentz, L. A. \& Oliveira, P. L. de. 2004. Solanum L. (Solanaceae) na Região Sul do Brasil. Pesquisas Botanica 54: 5-327.

Nee, M. 1999. Synopsis of Solanum in the New World. In: M. Nee, D. E. Symon, R. N. Lester \& J. P. Jessop (eds.), Solanaceae IV: Advances in Biology and utilization. Royal Botanic Gardens, Kew. Pp. 285-333.

2001. Index to Solanum epithets and associated genera, 340p.

Plowmam, T. C. 1998. (orgs. Knapp \& Press, J. R.) A revision of the South American species of Brunfelsia (Solanaceae). Fieldiana, Bot. n.s. 39: 1-135.

Rojas, C. B. \& Nessi, A. M. 1998. El gênero Physalis (Solanaceae) de Venezuela. Acta Botanica Venezuelica 21(2): 11-42.

Sendtner, O. 1846. Solanaceae et Cestrineae. In: Martius, C. F. P. von (ed.). Flora brasiliensis 10: 5-228.

Veloso, H. P.; Rangel-Filho, A. L. R. \& Lima, J. C. A. 1991. Classificação da vegetação brasileira, adaptada a um sistema universal. Rio de Janeiro, IBGE, Departamento de Recursos Naturais e Ambientais. 124p.

Vidal, U. de A. 1995. A família Bromeliaceae na Reserva Ecológica Rio das Pedras, Mangaratiba, Rio de Janeiro, Brasil. Dissertação de Mestrado. Museu Nacional/ Universidade Federal do Rio de Janeiro. 
